\title{
Effect of Calcium Hydroxide on the Microhardness of Root Dentin of Primary Tooth
}

\author{
Saeromi Jun', Jong-Bin $\mathrm{Kim}^{2}$, Seung-Hoon Yoo ${ }^{1}$ \\ ${ }^{\prime}$ Department of Pediatric Dentistry, School of Dentistry, Dankook University, ${ }^{2}$ Kizwell Dental Clinic
}

\section{Abstract}

Calcium hydroxide mixture medicaments can nearly be considered to be the ideal primary tooth filling material. However, long-term application of calcium hydroxide combinations as an intra canal medicament softens dentin. The aim of this study was to evaluate the effect of calcium hydroxide on the microhardness of root dentin of primary tooth.

For the study, 60 extractedprimary incisors were divided into 3 groups (no medicament, calcium hydroxide/iodorform mixture, and calcium hydroxide/distilled water mixture). After the cleansing and shaping of canals, calcium hydroxide medicaments were applied and stored for different periods of time (1, 7, 30, 90 days). The root was horizontally sectioned into $2 \mathrm{~mm}$ thick specimens and the microhardness was measured using Vickers microhardness tester.

The results were as follows :

Root dentin microhardness of primary teeth decreased with long term exposure to calcium hydroxide medicaments according to the experimental period and showed statistically significance $(p<0.05)$.

Root dentin microhardness of primary tooth filled with calcium hydroxide mixed with distilled water showed more decrease than filled with Vitapex and showed statistically significance $(p<0.05)$.

Root dentin microhardness of a control group without exposure to calcium hydroxide decreased according to the experimental period and showed statistically significance $(p<0.05)$.

Key words : Calcium hydroxide, Root dentin microhardness, Pulpectomy

\section{I. 서 론}

치수절제술은 치수까지 우식이 진행된 치아에 있어서 박테리 아와 그 산물을 제거하고 치근을 밀폐하여 치아와 치주조직을 유지하고 회복하는 술식이며 유치에 있어서는 자연적으로 탈락 될 때까지 치아의 기능을 유지하며 계승 영구치에 해로운 영향 을 미치지 않도록 하여야 한다 ${ }^{11}$.

유치의 이상적인 근관 충전제는 반드시 항세균효과가 있어야 하고 치근이 흡수되는 시점과 동시에 흡수가 가능하여 영구치
배와 치근 주변 조직에 위해작용을 끼쳐서는 안 되며, 근관에 쉽게 충전이 가능하고 치근벽과 접착이 잘 되며 수축되어서는 안 된다. 만일 치근첨을 넘어선다면 흡수가 가능하고 제거가 필 요할 때 쉽게 제거가 가능해야 하며 방사선 불투과성을 가지는 것이 좋고 치아의 변색을 야기해서는 안 된다2).

1930년 Sweet에 의해 처음 소개된 산화아연 유지놀은 유치 의 근관 충전제로 가장 널리 사용되었다 ${ }^{3)}$. 하지만 과충전 되었 을 때 흡수에 저항하는 단단한 백악질을 형성하여 치조골에 남 아 몇 달에서 몇 년까지 존재하며 염증을 유발할 수 있고, 계승 
영구치의 맹출로에 영향을 미쳐 계승치의 굴절을 초래한다는 단점을 가진다 ${ }^{3.4}$.

이를 대체할 약물로 수산화칼슘이 소개되었다. 높은 $\mathrm{pH}$ 의 수 산화칼슘은 박테리아 수를 감소시키고 염증과정의 국소적 완충 제로 작용한다 ${ }^{5}$. 수산화칼슘과 $40 \%$ 요오드화포름, 실리콘 오 일의 혼합제제는 살균성과 적용의 용이함으로 우수한 유치 근 관충전제로 평가되고 있다 ${ }^{5-7)}$.

하지만 수산화칼슘을 장기간 적용할 경우 치근 상아질에 미 치는 부정적인 영향이 논의되고 있으며 많은 연구에서 영구치 근관에 수산화칼슘을 적용 후 상아질의 경도의 감소가 확인되 었다 ${ }^{8-13)}$. Grigorato 등'2)은 사람의 상아질에 수산화칼슘을 1 주 일 적용하였을 때 상아질의 굴곡 강도가 감소한다고 보고하였 고, Andreasen 등13)은 미성숙 치근에 장기간 수산화칼슘을 적 용하였을 때 상아질의 물리적 성질 변화로 치근 파절이 증가함 을 보고하였다. Koshy 등 ${ }^{14)}$ 은 영구치근에서 수산화칼슘을 근관 내 적용 시 기간에 따른 상아질 미세경도의 감소를 보고하였다.

유치의 경우 치수절제술 후 근관 충전제의 적용이 보다 장기 간 요구됨에도 불구하고 유치 치근에 수산화칼슘 제제가 미치 는 영향에 대한 연구는 부족하다고 사료된다. 따라서 본 연구에 서는 수산화칼슘 제제의 적용 기간에 따라 유치 치근 상아질의 미세경도를 측정하여, 수산화칼슘의 적용이 유치 치근 상아질 의 미세경도에 미치는 영향을 평가하고자 하였다.

\section{II. 연구 재료 및 방법}

\section{1. 연구 재료}

교정적인 필요 혹은 외상으로 인한 탈구로 생리적 치근 흡수 가 $1 / 3$ 이상 진행되지 않은 시기에 발거된 60 개의 상악 유전치 를 이용하였다. 치수를 침범한 우식이나 파절 및 치수 치료의 병력이 없는 건전한 치아를 선택하였으며, 무작위로 20 개 씩 3 개의 군으로 분류하였다.

실험에 사용된 치아는 발치 직후 치근부에 남아있는 연조직 과 이물질을 스케일러를 사용하여 제거하고 $0.1 \mathrm{M}$ thymol 용 액에 보관하였다.

\section{2. 연구 방법}

\section{1) 치아의 근관 확대, 성형 및 세정}

치아는 근관 와동을 개방한 후 \#10 K 파일을 이용하여 작업 장을 측정하고, \#10, \#15, \#20 K 파일을 이용하여 치근단공 상방 $1 \mathrm{~mm}$ 까지 초기 근관 형성을 하였다. 그 후 \#25, 30, 35 $\mathrm{H}$ 파일을 이용하여 근관 확대와 성형을 시행하였으며 매 기구 작업마다 충분한 생리식염수(Daihan Co., Seoul, Korea)를 사용하여 근관 내를 세정하였다. 수기구 조작이 완료된 후 $1 \%$ 로 희석한 차아염소산나트륨 용액 $(\mathrm{NaOCl}$, Duksan pure chemical Co., Korea) $5 \mathrm{ml}$ 를 1 분간 적용하였고, 최종적으로 $20 \mathrm{ml}$ 증류수로 근관을 세정하고 페이퍼 포인트로 건조시켰다.
2) 수산화 칼슘의 적용 및 군의 분류

1 군은 대조군으로 개방된 근관의 치관부 및 근단부를 가봉재 (Caviton, GC, Japan)로 폐쇄하였고, 2군은 수산화칼슘과 요 오드포름의 혼합 제제(Vitapex, Neodent., Japan)를 근관 내 에 적용하였다. 3 군은 순수한 수산화칼슘 분말(Sigma aldrich Co., USA)에 증류수를 섞은 후 근관 내에 적용하였다.

준비된 각 군의 표본은 방사선 사진을 촬영하여 근관 내부에 수산화칼슘이 충분히 적용되었는지 확인하였다. 이 후 미세누 출을 막기 위해 개방한 근관 와동은 가봉재를 적용 후 $\mathrm{RM}-$ GI(Fuji II LC, GC, Japan)를 이용하여 폐쇄하였고, 자가 중 합형 교정용 레진(Orthodontic resin, Dentsply Co., USA) 에 치근부를 매몰한 후 실험 기간 동안 치아는 생리 식염수에 보관하였다.

각 그룹의 표본으로 군당 5 개 치아를 배정하여 24시간, 7 일, 30 일, 90 일 후 미세경도를 측정하였다.

\section{3) 미세경도를 측정하기 위한 시편의 준비}

계획된 수산화칼슘의 적용 기간이 지난 후 고속 절단기 (Metsaw RB 205, R\&B, Korea)를 이용하여 치근을 $2 \mathrm{~mm}$ 두께로 수평으로 절단하여 치근의 중앙부에서 시편을 획득하였다.

각 군당 5 개의 준비된 시편을 1200 grit, 2500 grit 실리콘 카바이드 페이퍼로 연마하여 활택한 표면을 형성하였다.

\section{4) 미세경도의 측정}

비커스 미세경도 측정기(HM-122, Akashi Co., Japan)를 이용하여 시편의 표면에서 미세경도를 측정하였다. 압흔은 비 커스 압입자로 형성되며, 각 시편의 표면에 $300 \mathrm{~g}$ 의 힘으로 15 초 동안 하중을 가하였다. 측정부위는 근관 내면으로부터 백악 질 외면으로 $500 \mu \mathrm{m}$ 위치로 시편의 협측, 설측, 근심측, 원심 측의 네 지점에서 각각 두 번씩 측정하여 (Fig. 1) 그 평균 값으 로 다음의 수식을 통해 미세경도 값을 산출하였다.

$$
\mathrm{VHN}=1854.4 \mathrm{P} / \mathrm{d}^{2} \text {, }
$$

( $P=$ load, in grams, $d=$ diagonal of indentation, in micrometers)

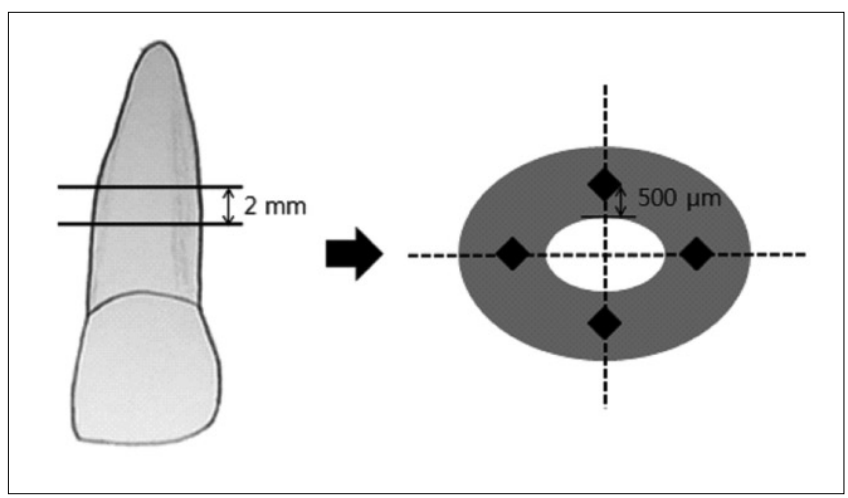

Fig. 1. Diagram of specimen preparation and measuring point of Vickers microhardness test. 


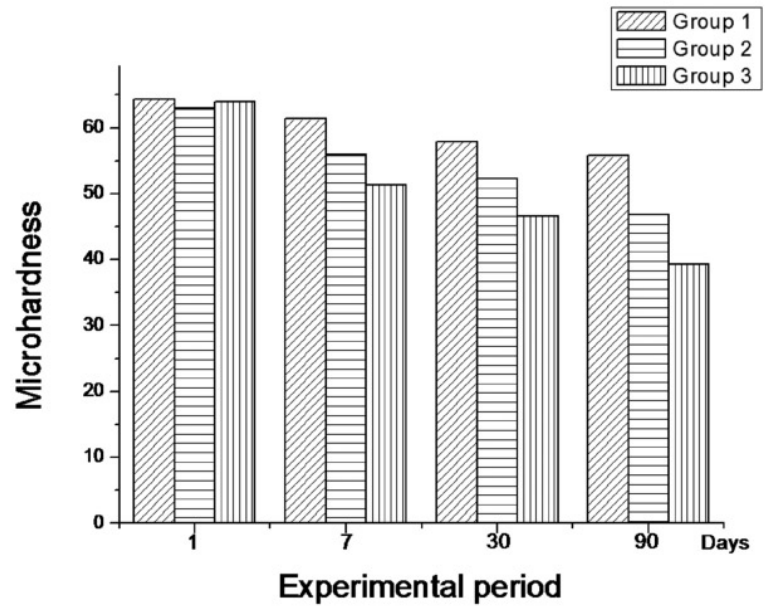

Fig. 2. The mean values of peri-canal dentin microhardness reduction of 3 groups according to experimental period.

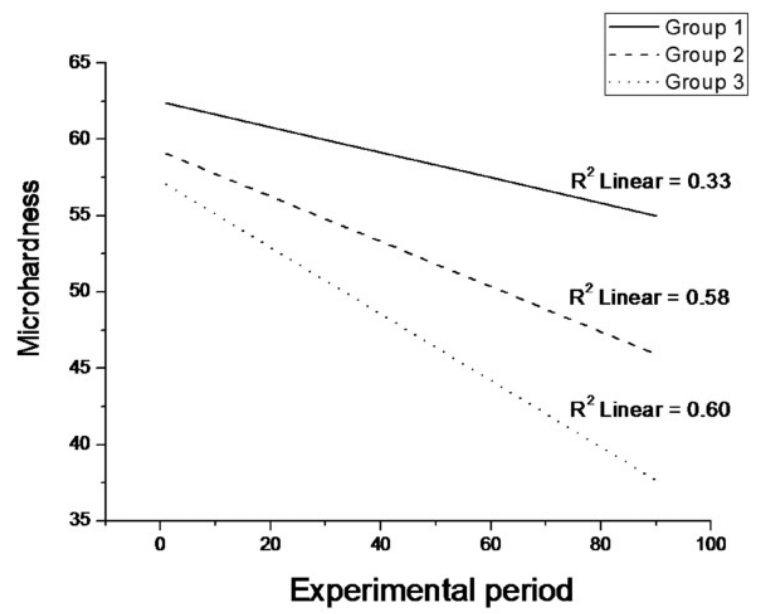

Fig. 3. Regression analysis of peri-canal dentin microhardness reduction of each groups according to experimental period.

Table 1. The mean and standard deviation values of the microhardness test of each group according to experimental period

\begin{tabular}{ccccc}
\hline Group & 1 day & 7 days & 30 days & 90 days \\
\hline 1 & $64.32 \pm 7.16$ & $61.35 \pm 2.85^{*}$ & $57.88 \pm 1.44^{*}$ & $55.75 \pm 1.54^{*}$ \\
2 & $62.95 \pm 5.66$ & $55.87 \pm 3.48^{*}$ & $52.26 \pm 2.36^{*}$ & $46.88 \pm 1.92^{*}$ \\
3 & $63.98 \pm 7.20$ & $51.35 \pm 2.45^{*}$ & $46.56 \pm 2.23^{*}$ & $39.34 \pm 2.55^{*}$ \\
\hline
\end{tabular}

Kruskal-Wallis test and Mann-Whitney test(*: $p<0.05)$

5) 통계 분석

통계 분석은 SPSS 17.0(SPSS Inc., Chicago, IL, U.S.A) 을 이용하여 Kruskal-Wallis test로 변수 간의 상호관계를 확 인하였으며, 사후 검정으로 Mann-Whitney test를 시행하였 다. 시간에 따른 미세경도 값의 감소량은 선형 회귀분석을 통해 추이를 분석 하였다. 각 통계 방법의 유의 수준은 0.05 로 설정 하였다.

\section{III. 연구 성적}

실험에 사용된 시편의 근관 내벽으로부터 백악질까지의 평균 길이는 $1.26 \pm 0.24 \mathrm{~mm}$ 이었다. 각 근관 충전제의 적용 기간 에 따른 치근 상아질의 미세경도의 측정값은 Table 1 과 같으 며, Fig. 2는 그래프로 표현한 것이다.

각 군은 약제의 적용 기간에 따라 유의한 미세경도의 감소를 나타내었다(Fig. 3) $(p<0.05)$.

Table 2 는 각 약제의 적용 기간에 따른 미세경도의 감소량이 다. 대조군에서도 기간에 따른 미세경도의 감소가 나타났으며, 2군에서는 7일 후에 $6.45 \%, 30$ 일 후에는 $10.69 \%, 90$ 일 후에 는 $17.42 \%$ 의 감소를 보였다. 3 군에서는 7 일 후 $8.57 \%, 30$ 일 후 $16.07 \%, 90$ 일 후에는 $24.64 \%$ 의 감소를 보였다. 모든 군 의 기간에 따른 치근 상아질 미세경도의 감소량은 통계적으로 유의하였으며, 각 군간에 유의한 차이를 나타내었다 $(p<0.05)$. 감소량은 3 군, 2 군, 1 군의 순으로 크게 나타났다 $(p<0.05)$.
Table 2. Microhardness reduction according to experimental period (\%)

\begin{tabular}{cccc}
\hline Group & 7 days & 30 days & 90 days \\
\hline Group 1 & $2.97^{*}$ & $7.08^{*}$ & $12.63^{*}$ \\
Group 2 & $6.45^{*}$ & $10.69^{*}$ & $17.42^{*}$ \\
Group 3 & $8.57^{*}$ & $16.07^{*}$ & $24.64^{*}$ \\
\hline
\end{tabular}

Kruskal-Wallis test and Mann-Whitney test $\left.{ }^{*}: p<0.05\right)$

\section{IV. 총괄 및 고찰}

유치의 치수 절제술의 성공은 나이, 외상 병력, 병리적 치근 흡수, 연관된 골과 치근의 흡수, 농양과 누공, 그리고 치수의 상 태 등 여러 가지 요소에 영향을 받는다 ${ }^{15)}$. 또한 근관의 세척과 충전을 위해 선택한 약제에 따라 치료 결과가 크게 달라질 수 있다 ${ }^{16)}$

일반적으로 유치의 근관 충전에 사용되는 약제로 산화아연유 지놀, 요오드포름, 수산화칼슘 제제가 있다 ${ }^{17)}$. 최근까지 가장 널 리 사용되었던 산화아연 유지놀 제제는 느린 흡수성과 치근단 조직에 대한 자극, 영구 계승치의 맹출로에 미치는 영향 4.18$)$ 으로 인해 유치 근관충전제로서의 사용이 감소되고 있으며, 현재는 수산화칼슘 제제가 여러 장점으로 각광 받고 있다. 수산화칼슘 은 뛰어난 항균작용과 낮은 세포독성으로 치수 복조술, 치수 절 단술, 치수 절제술 등의 다양한 치료에 있어 광범위하게 적용될 수 있다 ${ }^{19)}$. 파골세포와 파치세포는 수산화칼슘에 의해 활동성이 
저하되고 골 생성 기전이 촉진된다. 칼슘 이온들은 국소적인 염 증을 줄이고 재광화 과정을 개시하는 면역학적 반응에 작용한 다 ${ }^{20)}$.

유치의 근관 충전제로써 수산화칼슘의 단일 사용은 근관 내 에서 급속하게 흡수되고, 이로 인한 치근단 폐쇄의 실패와 빈번 한 내흡수가 보고되었다 ${ }^{1621)}$. 이러한 단점을 극복하기 위해 요 오드포름과 수산화칼슘의 혼합제제로 Vitapex가 소개되었다. 요오드포름은 근관 내 세균의 감소에 효과적이고 치근단에서 쉽게 흡수되며 조직에 위해작용을 야기하지 않는 제제이다. Vitapex는 약제의 적용이 용이하고, 흡수 속도가 치근보다 약 간 빠르며, 영구치에 무해하며 방사선 불투과성을 보이는 장점 을 가진다 ${ }^{7}$. Mortazavi와 Mesbahi ${ }^{22)}$ 는 유치의 치수절제술에 있어서 Vitapex가 전통적으로 사용된 $\mathrm{ZOE}$ 보다 성공률이 높고 (100\% vs 78.5\%) 치근첨을 통해 누출되었을 때 쉽게 제거된 다는 것을 보고하였다. 요오드포름과 수산화칼슘을 사용한 다 른 연구에서도 85 100\% 범위로 치아 방사선 투과성 병소의 해소를 보였다 ${ }^{23)}$. 이와 같이 많은 연구에서 요오드포름과 수산 화칼슘의 혼합 제제는 좋은 치유효과를 부여함과 동시에 과도 한 충전제에 대해 탁월한 흡수성을 보이는 우수한 제제임이 입 증되었다.

수산화칼슘 제제의 유용한 효과는 장기간의 적용을 필요로 하며 근관의 충분한 소독 작용을 위해서는 최소 일주일 이상 적 용해야 하고 ${ }^{24)}$ 치근단 병소가 존재할 경우 회복을 위해 한 달 이 상 적용이 필요하다 ${ }^{25)}$. 유치의 근관 충전제로 사용 시에는 영구 계승치가 맹출 하는 시기까지 근관 내에 유지되어야 한다. 그러 나 수산화칼슘의 장기간 적용이 약제의 강한 염기성으로 인해 치근 상아질의 $\mathrm{pH}$ 를 10 이상으로 유지하게 하고, 이로 인한 상 아질의 단백질 구조의 변성으로 치근 상아질의 약화가 야기된 다는 점이 논의되었다 ${ }^{8,13,14)}$. 영구치를 대상으로한 연구에서 Doyon 등9)은 수산화칼슘의 장기간 적용 시 치아의 파절 저항 성이 10 20\% 감소한다고 보고하였고. White 등 26$)$ 은 5 주 동 안 수산화칼슘을 적용 시 상아질의 강도가 $32 \%$ 감소한다고 하 였다.

본 연구에서는 수산화칼슘 제제의 적용에 따른 유치 상아질 표면의 변화를 조사하기 위해 비커스 압입 미세경도를 측정하 였다. 미세경도는 항복강도와 인장강도, 탄성계수와 결정 구조 의 안정성과 같은 여러 요소에 영향을 받아 치아 구조의 표면 변화에 대한 감지가 가능하다 ${ }^{27}$. 그 중에서도 비커스 압입 미세 경도 측정법은 표면의 상태에 덜 민감하고 작은 시편도 정확하 게 측정이 가능하다 ${ }^{14}$.

유치 상아질의 미세경도에 관한 연구는 많지 않으며, Sakai 등ㅇ)은 유치 상아질의 미세경도 값이 영구치보다 크게 나타난다 고 보고한 바 있으나 일반적으로 유사한 것으로 알려져 있다 ${ }^{29}$. 심부 상아질은 표면 상아질에 비해 상아세관의 밀도가 높아 미 세경도가 감소하고 약제의 효과에 있어서 변화 양상이 더 크게 나타난다 ${ }^{30}$. 본 연구에서는 치근 중앙부에서 시편을 획득하여 근관 내벽으로부터 $500 \mu \mathrm{m}$ 의 심부 상아질에서 미세경도를 측 정하였다. 치수에 더 근접한 경우 연구에서 사용된 차아염소산
나트륨 용액이 미치는 영향을 배제할 수 없기 때문이었다.

본 연구의 결과에 따르면 7일 후 치근 상아질의 미세경도는 수산화칼슘과 요오드포름의 혼합 제제를 적용한 군에서는 $6.45 \%$, 수산화칼슘과 증류수를 혼합한 군에서는 $8.57 \%$ 감소 하였다. 이는 영구치를 대상으로한 이전의 연구에 비해 보다 빠 른 변화이며, 그 원인으로 유치와 영구치 상아질의 구조적 차이 를 들 수 있다. 유치 상아질은 영구치에 비해 덜 광화되어 있고, 직경이 작다. 또한 상아세관이 “S” 형태를 띄고 있는 영구치와 달리 유치 상아세관은 직선으로 주행한다 ${ }^{31}$. 이로 인해 우식의 진행이 더 빠르다고 알려져 있으며, 약제와 같은 물질의 투과성 또한 영구치에 비해 빠르게 일어날 수 있음을 추정할 수 있다 ${ }^{32}$.

Vieira-Andrade 등 ${ }^{33}$ 의 연구에 따르면 치수 절제술의 과정 이 유치의 치근흡수를 가속화 시킬 수 있다고 하였다. 유치에서 생리적 치근흡수가 활성화됨에 따라 조상아세포, 백악아세포, 섬유아세포가 감소하고, Howship's lacunae에 파골세포가 증 가한다 ${ }^{34}$. Ravi와 Subramanyam ${ }^{35)}$ 은 수산화칼슘의 높은 $\mathrm{pH}$ 가 파치세포의 생성을 자극하여 유치 치근의 흡수를 촉진할 수 있다는 가능성에 대해 보고하였으나 아직은 논란의 여지가 많 다. 본 연구에서 수산화칼슘이 유치 상아질의 미세경도의 감소 와 유의하게 연관성을 보이는 것을 확인하였다. 이는 앞서 언급 한 인자들에 더불어 촉진된 치근의 흡수를 가속화 하는데 영향 을 미칠 수 있을 것이다. 그러나 유치 조기 탈락과 관련된 치수 절제술 및 수산화칼슘의 영향에 관한 더 많은 연구가 필요하다. 수산화칼슘은 분말 형태로 공급되어 증류수, 생리 식염수, 국 소마취제, Ringer's solution 등과 같은 다양한 용매와 혼합하 여 사용이 가능하다. 실리콘 오일, 글리세린과 같이 점도가 높 은 용매를 사용할 경우 조작성의 향상을 기대할 수도 있다 ${ }^{36)}$. 본 연구에서 수산화칼슘을 증류수에 혼합하여 적용한 경우 수산화 칼슘과 요오드포름의 혼합 제제에 비해 미세경도의 감소에 더 큰 영향을 받는 것으로 나타났으며 이는 이전에 발표된 연구들 과 일치하는 결과이다 ${ }^{8.37)}$. Safavi와 Nakayama ${ }^{37}$ 는 글리세린 은 수산화칼슘을 효과적으로 용해시키지 못하기 때문에 용매로 써 적절하지 않고, 증류수에서 잘 용해되어 수산기와 칼슘이온 으로 분해되므로 더 강한 염기성을 띄게 되며 이로 인해 탁월한 항세균효과를 보인다고 하였다. 이렇게 강한 염기성이 앞서 언 급한 바와 같이 콜라겐 섬유간의 결합과 수산화인회석 결정의 분열을 초래하여 상아질 미세경도의 감소를 일으킨다 ${ }^{13)}$. Hasheminia 등은 순산화칼슘을 글리세린, 생리 식염수, 증류 수에 각각 혼합하여 적용했을 때 상아질 미세경도의 변화를 조 사하여 증류수를 적용한 경우 미세경도의 감소가 가장 크게 나 타나는 것을 발견하였다.

차아염소산나트륨 용액은 낮은 표면 장력, 항균작용을 가지 고 치수조직의 용해를 촉진하며 수산화칼슘을 포함한 근관 약 제와 함께 사용할 경우 이러한 효과가 증대된다고 알려져 있다 ${ }^{38)}$. 세정 및 소독의 효과에 있어서는 $5.25 \%$ 차아염소산나트륨 용액이 가장 월등하나 높은 독성으로 인해 임상적으로 $2.6 \%$, $1 \%$ 차아염소산나트륨 용액의 사용이 추천되고 있다 ${ }^{39}$. 차아염 소산나트륨은 유기질을 산화시키고 콜라겐 구조의 변성을 야기 
하여 상아질의 화학적 구조의 변화를 통해 그 물리적 성질을 변 화시킨다 ${ }^{40)}$. Oliveira 등 40$)$ 은 $1 \%$ 차아염소산나트륨 용액을 15 분간 적용 할 경우 $1000 \mu \mathrm{m}$ 의 상아질까지 미세경도가 감소한 다고 보고하였다. Slutzky-Goldberg 등1ㅣㅇㅣ 차아염소산나트륨 용액을 사용한 근관세척 시 적용 시간, 농도에 따른 상아질의 미세경도의 변화를 연구한 결과 적용시간이 길수록, 농도가 높 을수록 미세경도의 감소가 크게 나타났고, $2.5 \%$ 의 농도로 5 분 간 적용하였을 때에는 $500 \mu \mathrm{m}$ 의 상아질에서 유의한 영향이 나 타나지 않았다. 본 연구에서는 근관 내 미생물 및 유기물 잔사 의 제거를 위해 $1 \%$ 차아염소산나트륨 용액으로 1 분간 근관 세 척을 하였다. $1 \%$ 차아염소산나트륨 용액은 미국소아치의학회 (AAPD) 등에서 추천되는 유치 근관 세척제이다. 낮은 농도의 최소한의 적용으로 차아염소산나트륨 용액의 영향을 배제하고 자 하였음에도 불구하고, 본 연구의 결과 대조군의 경우에도 미 세경도가 감소하는 양상이 나타났다. Fusayama와 Menda ${ }^{42}$ 는 생활치에 비해 치수를 제거한 치아의 상아질 미세경도가 유 의하게 감소한다고 보고하였다. 대조군의 변화는 이러한 치수 절제술 술식 자체에 기인한 것으로 여겨진다.

본 연구에서는 제한된 조건하에 수산화칼슘이 유치 치근상아 질의 미세경도에 미치는 영향을 조사하였다. 그러나 실제 생체 내의 영향은 다른 여러 인자에 의한 복합적인 영향을 받게 되므 로 조절된 실험실에서의 연구가 아닌 생체 내의 연구를 통한 조 사를 필요로 한다.

또한 유치에 있어서 근관 내 약제의 적용은 때로 5 년 이상의 장기간 유지를 필요로 한다. 따라서 더 장기간의 효과에 대한 연구가 필요할 것이다.

유치의 근관은 특유의 해부학적 구조, 부근관, 영구 계승치의 근접, 생리적 치근 흡수의 진행으로 기구를 사용한 물리적 세정 이 용이하지 않다. 따라서 근관 약제의 화학적 작용이 큰 영향 을 미친다 ${ }^{40)}$. 수산화칼슘 제제는 현재까지 유치의 근관충전제로 서 이상적으로 평가되고 있지만 본 연구에서 밝혀 진 바와 같이 장기간의 수산화칼슘제제의 적용에 의한 치근의 약화는 개선해 야 할 과제로 남아 있으며, 치근의 구조적인 약화 없이 보다 장 기간의 적용에도 안전한 재료의 개발이 필요할 것으로 사료된다.

\section{V. 결 론}

수산화칼슘 근관 충전제가 유치의 치근 상아질의 미세경도에 미치는 영향을 조사한 결과, 다음과 같은 결론을 얻을 수 있었다.

수산화칼슘 근관 충전제를 유치의 근관에 적용 시 기간에 따 라 치근상아질의 미세경도가 감소하였으며, 이는 통계적으로 유의하였다 $(p<0.05)$.

수산화칼슘과 요오드화포름의 혼합제제(Vitapex)에 비해 수 산화칼슘을 증류수에 혼합하여 적용한 경우 유치 치근상아질의 미세경도가 더 급격하게 감소하였으며, 이는 통계적으로 유의 하였다 $(p<0.05)$

수산화칼슘을 적용하지 않은 대조군에서도 7일, 30일, 90일 후 기간에 따라 치근상아질의 미세경도가 감소하였으며, 이는
통계적으로 유의하였다 $(p<0.05)$.

이상의 결과에서 확인된 바와 같이 수산화칼슘제제의 적용에 의한 치근의 약화는 개선해야 할 과제로 남아 있으며, 치근의 구조적인 약화 없이 보다 장기간의 적용에도 안전한 재료의 개 발이 필요할 것이다.

\section{References}

1. Chugal NM, Clive JM, Spangberg LS : Endodontic infection: some biologic and treatment factors associated with outcome. Oral Surg Oral Med Oral Pathol Oral Radiol Endod, 96:81-90, 2003.

2. Rifkin A : The root canal treatment of abscessed primary teeth: A three to four year follow-up. $J$ Dent Child, 49:428-431, 1982.

3. Primosch RE, Glomb TA, Jerrell RG : Primary tooth pulp therapy as taught in predoctoral pediatric dental programs in the United States. Pediatr Dent, 19:118-22, 1997

4. Barker BCW, Lockett BC : Endodontics experiments with resorbable pastes. Aust Dent J, 16:364-72, 1971.

5. Rehman K, Saunders WP, Sharkey SW : Calcium ion diffusion from calcium hydroxide-containing materials in endodontically-treated teeth: an in vitro study. Int Endod J, 29:271-9, 1996.

6. Nurko C, Garcia-Godoy F : Evaluation of a calcium hydroxide/iodoform past(Vitapex) in root canal therapy for primary teeth. J Clin Pediatr Dent, 23:28994, 1999.

7. Barr ES, Flaitz CM, Hicks JM : A retrospective radiographic evaluation of primary molar pulpectomies. Pediatr Dent, 13:4-9,1991.

8. Hasheminia SM, Norouzynasab S : Effect of three different calcium hydroxide mixtures on root dentin microhardness. J Dental Medicine, 20:119-124, 2007.

9. Doyon GE, Dumsha T, Fraunhofer AVJ : Fracture resistance of human root dentin exposed to intracanal calcium hydroxide. J Endod, 31:895-87, 2005.

10. Lee YH, Park HW, Seo HW, et al. : Reinforcement of fracture resistance after apexification : case report. J Korean Acad Pediatr Dent, 39:397-403, 2012

11. Cvek M : Prognosis of luxated non-vital maxillary incisors treated with calcium hydroxide and filled with gutta-percha. A retrospective clinical study. Endod Dent Traumatol, 8:45-55, 1992. 
12. Grigoratos D, Knowles J, Ng YL, et al. : Effect of exposing dentine to sodium hypochlorite and calcium hydroxide on its flexural strength and elastic modulus. Int Endod J, 34:113-9, 2001.

13. Andreasen JO, Farik B, Munksgaard EC : Longterm calcium hydroxide as a root canal dressing may increase risk of root fracture. Dent Traumatol, 18:134-37, 2002.

14. M. Koshy, M. Prabu, V. Prabhakar : Long Term Effect Of Calcium Hydroxide On The Microhardness Of Human Radicular Dentin - A Pilot Study. Int $J$ Dent Sci, 9, 2010.

15. Rocha MJ, Cardoso M : Survival analysis of endodontically treated traumatized primary teeth. Dent Traumatol, 23:340-7, 2007.

16. Rodd HD, Waterhouse PJ, Moffat MA, et al. : Pulp therapy for primary molars. Int $J$ Paediatr Dent, 16:15-23, 2006.

17. Camp JH : Pulp therapy for primary and young permanent teeth. Dent Clin North Am, 28: 651-68, 1984.

18. Coll JA, Sadrian R : Predicting pulpectomy success and its relationship to exfoliation and succedaneous dentition. Pediatr Dent, 18:57-63, 1996.

19. Fava LR, Saunders WP : Calcium hydroxide past: Classification and clinical indications. Int Endod $J$, 32:257-82, 1999.

20. Segura JJ, Llamas R, Calvo JR, et al. : Calcium hydroxide inhibits substrate adherence capacity of macrophages. J Endod, 23:444-7, 1997.

21. Pitts A : histologic comparison of Calcium Hydroxide plugs and dentin plugs used for the control of GP root canal filling materials. J Endod, 10:283-293, 1984.

22. Mortazavi M, Mesbahi M : Comparison of zinc oxide and eugenol, and Vitapex for root canal treatment of necrotic primary teeth. Int $J$ Paediatr Dent, 14:41724, 2004.

23. Chawla HS, Mani SA, Tewari : A Calcium Hydroxide as a root canal filling material in primary teeth- a pilot study. J Indian Soc Pedo Prev Dent, 16:90-92. 1998.

24. Sjo"gren U, Figdor D, Sundqvist, et al. : The antimicrobial effect of calcium hydroxide as a shortterm intracanal dressing. Int Endod J, 24:119-25, 1991.

25. Nunes AC, Rocha MJ : Hydroxyl and calcium ions diffusion from endodontic materials through roots of primary teeth - in vitro study. J Appl Oral Sci, 13: 187-92, 2005.

26. White JD, Lacefield WR, Eleazer PD, et al. : The effect of three commonly used endodontic materials on the strength and hardness of root dentin. $J$ Endod, 28:828-30, 2002.

27. Namazikhah MS, Nekoofar MH, Bryant ST, et al. : The effect of $\mathrm{pH}$ on surface hardness and microstructure of mineral trioxide aggregate. Int Endod $\mathrm{J}$, 41:108-16, 2008.

28. Sakai J, Fumijazu K, Toshiaki H : Evaluation of Microhardness of Permanent and Primary Tooth. Jap soc ortho biomech, 24:133-137, 2003.

29. Korean Academy of pediatric dentistry : Pediatric, adolescent dentistry. 4th ed. 66-67, 2007.

30. Pashley D, Ukabe A, Parham P : The relationship between dentin microhardness and tubule density. Endod Dent Traumatol, 1: 176-179, 1985.

31. Chowdhary N, Subba Reddy VV : Dentin comparison in primary and permanent molars under transmitted and polarised light microscopy: An in vitro study. J Indian Soc Pedod Prev Dent, 28:167-72, 2010.

32. Pascon FM, kantovitz KR, Puppin-Rontani RM : Influence of cleansers and irrigation methods on primary and permanent root dentin permeability: a literature review. Braz J Oral Sci, 5:1063-1069, 2006.

33. Vieira-Andrade RG, Drumond CL, Ramos-Jorge, et al. : Inflammatory root resorption in primary molars: prevalence and associated factors. ML Braz Oral Res, 26:335-40, 2012.

34. Lee JE, Lee JH, Choi BJ, et al. : Root resorption of primary teeth without permanent successors. $J$ Korean Acad Pediatr Dent, 36:625-630. 2009

35. Ravi GR, Subramanyam RV : Calcium hydroxideinduced resorption of deciduous teeth: A possible explanation. Dent Hypotheses, 3:90-4, 2012.

36. Rivera EM, Williams K : Placement of calcium hydroxide in simulated canals: comparison of glycerin versus water. J Endod, 20:445-8, 1994.

37. Safavi K, Nakayama TA : Influence of mixing vehicle on dissociation of calcium hydroxide in solution. $J$ Endod, 26:649-51, 2000.

38. Turkun M, Cengiz T : The effects of sodium hypochlorite and calcium hydroxide on tissue dissolution and root canal cleanliness. Int Endod J, 30: 335-42, 1997.

39. Ingle JI, Bakland LK : Endodontics, Fifth Edition, 
Elsevier. 499, 2002.

40. Oliveira LD, Carvalho CAT, Jorge AOC, et al. : Effects of chlorhexidine and sodium hypochlorite on the microhardness of root canal dentin. Oral Surg Oral Med Oral Pathol Oral Radiol Endod, 104:125128, 2007.
41. Slutzky-Goldberg I, Maree M, Heling I, et al. : Effect of Sodium Hypochlorite on Dentin Microhardness. J Endod, 30:880-882, 2004.

42. Fusayama T, Maeda T : Effect of pulpectomy on dentin hardness. J Dent Res, 48:452-60, 1969. 
국문초록

수산화칼슘 근관충전제의 적용이 유치 치근상아질의 미세경도에 미치는 영향

\author{
전새로미 ${ }^{1} \cdot$ 김종빈 $^{2} \cdot$ 유승훈 ${ }^{1}$
}

${ }^{1}$ 단국대학교 치과대학 소아치과학교실, ${ }^{2}$ 키즈웰치과

수산화칼슘 근관충전제는 뛰어난 항균작용과 낮은 세포독성으로 우수한 유치 근관충전제로 평가되고 있다. 하지만 수산화 칼슘을 근관 내 장기간 적용할 경우 치근 상아질에 미치는 부정적인 영향이 논의되고 있으며 많은 연구에서 영구치 근관에 수산화칼슘을 적용 후 상아질 경도의 감소가 확인되었다.

본 연구에서는 수산화칼슘 제제의 적용 기간에 따라 유치 치근 상아질의 미세경도를 측정하여, 수산화칼슘의 적용이 유치 치근 상아질의 미세경도에 미치는 영향을 평가하고자 하였다.

생리적 치근 흡수가 $1 / 3$ 이상 진행되지 않은 시기에 발거된 60 개의 상악 유전치를 각각 20 개 씩 대조군, 수산화칼슘과 요 오드포름의 혼합제제(Vitapex, Neodent., Japan), 수산화칼슘과 증류수의 혼합제제를 적용하는 3개의 군으로 분류하였다. 각 치아는 같은 과정의 치수 절제술을 시행한 후 교정용 레진에 매몰하여 군당 5 개 치아를 배정하고 24 시간, 7 일, 30 일, 90 일 후 치근 중앙부에서 $2 \mathrm{~mm}$ 두께의 시편을 획득하여 비커스 미세경도 측정기를 통해 미세경도를 측정하였다. 측정된 미세 경도 값은 Kruskal-Wallis test로 변수 간의 상호관계를 확인하였으며 사후 검정으로 Mann-Whitney test를 시행하였다. 시간에 따른 미세경도 값의 감소량은 선형 회귀분석을 통해 추이를 분석하였다.

수산화칼슘 근관 충전제가 유치의 치근 상아질의 미세경도에 미치는 영향을 조사한 결과, 다음과 같은 결론을 얻을 수 있 었다.

수산화칼슘 근관 충전제를 유치의 근관에 적용 시 기간에 따라 치근상아 질의 미세경도가 감소하였으며, 이는 통계적으로 유의하였다 $(p<0.05)$.

수산화칼슘과 요오드화포름의 혼합제제에 비해 수산화칼슘을 증류수에 혼합하여 적용한 경우 유치 치근상아질의 미세경도 가 더 급격하게 감소하였으며, 이는 통계적으로 유의하였다 $(p<0.05)$.

수산화칼슘을 적용하지 않은 대조군에서도 7 일, 30 일, 90 일 후 기간에 따라 치근상아질의 미세경도가 감소하였으며, 이는 통계적으로 유의하였다 $(p<0.05)$.

주요어: 수산화칼슘, 치근 상아질 미세경도, 치수절제술 